\title{
Raf1 interaction with Cdc25 phosphatase ties mitogenic signal transduction to cell cycle activation
}

\author{
Konstantin Galaktionov, ${ }^{1}$ Catherine Jessus, ${ }^{2}$ and David Beach ${ }^{1,3}$ \\ ${ }^{1}$ Howard Hughes Medical Institute, Cold Spring Harbor Laboratory, Cold Spring Harbor, New York 11724 USA; ${ }^{2}$ Laboratory \\ of Reproduction Physiology; URA Centre National de la Recherche Scientifique, Paris, France (CNRS) 1449, University of \\ Pierre and Marie Curie
}

The Ras and Raf1 proto-oncogenes transduce extracellular signals that promote cell growth. Cdc25 phosphatases activate the cell division cycle by dephosphorylation of critical threonine and tyrosine residues within the cyclin-dependent kinases. We show here that Cdc25 phosphatase associates with raf1 in somatic mammalian cells and in meiotic frog oocytes. Furthermore, Cdc25 phosphatase can be activated in vitro in a Raf1-dependent manner. We suggest that activation of the cell cycle by the Ras/Raf 1 pathways might be mediated in part by Cdc25.

[Key Words: Raf-1; Ras; Cdc25 phosphatase; signal transduction; cell cycle activation]

Received February 22, 1995; revised version accepted March 9, 1995.

In eukaryotic cells, a family of related cyclin-dependent kinases (cdks) regulate progression through each phase of the cell division cycle (Heichman and Roberts 1994; Hunter and Pines 1994; King et al. 1994; Sherr 1994). These proteins are subject to multiple levels of control, including association with regulatory subunits known as cyclins (Evans et al. 1983; Swenson et al. 1986; Koff et al. 1991; Lew et al. 1991; Matsushime et al. 1991; Xiong et al. 1991) and activating phosphorylation by cdk-activating kinase [(CAK) Solomon et al. 1992]. Cyclin/cdk complexes are also negatively regulated by at least two different mechanisms. First, the recently identified cdk inhibitors (p21, p16, p15, p18, and p27; El-Deiry et al. 1993; Gu et al. 1993; Harper et al. 1993; Serrano et al. 1993; Xiong et al. 1993; Guan et al. 1994; Hannon and Beach 1994; Polyak et al. 1994a; Toyoshima and Hunter 1994; Guan et al. 1994/ prevent cell cycle progression in the presence of DNA damage, contact inhibition, and senescence [(p21) Dulic et al. 1994; Noda et al. 1994], transforming growth factor- $\beta 1$ TGF- $\beta 1[(\mathrm{p} 15)$ Hannon and Beach 1994; (p27) Polyak et al. 1994b) or other unknown stimuli (p16, p18). Second, certain members of the cdk family (cdc2, cdk2) are inactivated by phosphorylation of threonine and tyrosine residues, usually at positions 14 and 15 (Draetta et al. 1988; Gould and Nurse 1989; Morla et al. 1989; Krek and Nigg 1991; Gu et al. 1992). These residues are conserved between fission yeast cdc2 and most of the human cdks (Meyerson et al. 1992).

In fission yeast, positive $(c d c 25)$ and negative (wee1 and mik1\} regulators of mitosis have been identified

${ }^{3}$ Corresponding author.
(Russell and Nurse 1986, 1987; Lundgren et al. 1991). Biochemical analysis demonstrated that Weel and Mikl are inhibitory tyrosine kinases that phosphorylate Tyr15 and possibly Thr-14 (Parker et al. 1991, 1992; Featherstone and Russell 1991), whereas Cdc25 is a specialized dual specificity phosphatase capable of dephosphorylating the same residues and activating the cyclin kinases (Dunphy and Kumagai 1991; Galaktionov and Beach 1991; Gautier et al. 1991; Millar et al. 1991; Strausfeld et al. 1991). The role of the single fission yeast cdc25 gene in regulating the $\mathrm{G}_{2} / \mathrm{M}$ transition is well documented (Russell and Nurse 1986; Millar et al. 1991). In humans, however, $c d c 25$ consists of a multigene family, the A, B, and C isoforms, which share $-40 \%-50 \%$ amino acid identity (Sadhu et al. 1990; Galaktionov and Beach 1991; Nagata et al. 1991). Both Cdc25A and Cdc25C have some function in mitosis (Galaktionov and Beach 1991; Millar et al. 1991). However, Cdc25A has also been found to be essential for DNA replication following serum stimulation of quiescent rat fibroblasts (Jinno et al. 1994). The precise role of each member of the human Cdc25 family in cell cycle progression has yet to be determined.

In Xenopus oocytes, which are blocked in prophase of the first meiotic division Cdc25 function is rate limiting for entry into M-phase. Cdc2 kinase in oocytes is complexed with mitotic cyclins but is inactive, apparently because of phosphorylation of Thr-14 and Tyr-15. Upon stimulation with progesterone or insulin, oocytes undergo the transition into meiosis (maturation). The crucial step in this process, activation of maturation promoting factor $(\mathrm{MPF})$ (cyclin $\mathrm{B} / \mathrm{Cdc} 2$ kinase), is effected 
by dephosphorylation of Cdc2 on Thr- 14 and Tyr- 15 by Cdc25. As a result of the inhibitory phosphate removal, $\mathrm{Cdc} 2$ histone $\mathrm{H} 1$ kinase is activated, causing the oocyte to progress into meiosis (Dunphy and Newport 1989; Gautier et al. 1989).

The ras and raf1 proto-oncogenes are essential elements of several signal transduction pathways (Stacey et al. 1991; Thomas et al. 1992; Wood et al. 1992). ras and raf1 become activated through various receptor and nonreceptor tyrosine kinases in response to extracellular stimuli (for review, see Hunter 1995; Marshall 1995). It has been shown that the Ras protein binds GTP and functions in part to promote membrane localization and activation of the Raf1 protein kinase (Leevers et al. 1994; Stokoe et al. 1994). The exact mechanism of Rafl activation is largely unknown (Marshall 1995) but might involve the 14-3-3 family proteins (Freed et al. 1994; Fu et al. 1994). Activated Rafl kinase then phosphorylates and activates MEK (Dent et al. 1992; Howe et al. 1992; Kyriakis et al. 1992), which results in MEK-dependent phosphorylation and activation of MAP kinases (MAPKs or ERKs; Ahn et al. 1991; Gomez and Cohen 1991; Kosako et al. 1992). These events constitute a signal transduction kinase "cascade," which is believed to be a central element of the cellular response to extracellular stimuli, including various mitogens (for review, see Herskowitz 1995; Marshall 1995). Current models suggest that the end result of this cascade is the phosphorylation and activation of transcription factors (for review, see Hill and Treisman 1995), which in turn activate cell proliferation. In Xenopus oocytes, however, the signal transduction cascade appears to activate meiotic maturation in the absence of new transcription. This suggests that a much more direct link between signal transduction and the cell cycle control machinery must exist.

In frog oocytes Rafl has been implicated in meiotic maturation that is mediated by progesterone and receptor tyrosine kinases [(RTK) Fabian et al. 1993a; Muslin et al. 1993; for review, see Heidecker et al. 1991]. Introduction of oncogenic forms of either Ras or Rafl causes precocious maturation of Xenopus oocytes, associated with activation of the cyclin $\mathrm{B} / \mathrm{Cdc} 2$ kinase. Because the major event in oocyte maturation is thought to be the activation of Cdc25, we investigated the potential link between Raf 1 and Cdc25 in mammalian cells and in Xenopus oocytes.

\section{Results}

\section{Raf1/Cdc25 association in meiotic oocytes}

To test for possible interaction between Raf 1 and Cdc25 we first employed Xenopus oocytes, a well-defined biological system devoid of transcriptional control. Cytoplasmic extracts were prepared from prophase oocytes, progesterone-matured oocytes, eggs activated by $\mathrm{Ca}^{2+}$ in the presence of cycloheximide, cAMP-blocked oocytes, and insulin-like growth factor-1 (IGF-1)-matured oocytes (see legend to Fig. 1; Materials and methods). Levels of histone $\mathrm{Hl}$ kinase activity in prophase, inter- phase, and metaphase extracts were found to be as described previously (Jessus and Beach 1992; Fig. 1A). Similar extracts were probed with antibodies against Xenopus Cdc25 (Kumagai and Dunphy 1992) or anti-human Raf1 antibodies that have been shown previously to cross-react with frog c-Rafl (see Materials and methods). The relevant proteins were clearly detected (Fig. 1B,C). As described previously (Kumagai and Dunphy 1992), frog Cdc25 undergoes a change in mobility from 70 to 90 $\mathrm{kD}$ apparent molecular mass in matured oocytes. At the same time, Rafl also shifts to a slightly higher molecular mass. In activated eggs (interphase) Cdc25 is present in mostly unphosphorylated form (Fig. 1B,D), whereas Raf 1 displays an altered mobility (Fig. 1C,E). These observations prompted us to check the kinase activity of Rafl in immunoprecipitates from prophase, metaphase, and activated egg (interphase) extracts. We found that Raf $1 \mathrm{ki}$ nase activity toward exogenous, recombinant MEK is activated in metaphase $\sim 5$ - to 10 -fold, and the activity at interphase is equal to or even lower than that in prophase, despite the interphase shift of Rafl (not shown).

To investigate a potential Rafl/Cdc25 interaction, equal amounts of extracts from interphase and activated oocytes and eggs were used for immunoprecipitations with anti-Cdc25 antibodies (Fig. 1D,E) or anti-Raf1 antibodies (Fig. 1F,G). These immunoprecipitates were then blotted with anti-Rafl (Fig. 1E,F) or anti-Cdc25 antibodies (Fig. 1D,G), respectively. A significant reciprocal immunoprecipitation of Raf 1 and Cdc25 was observed under each physiological condition (Fig. 1D-G).

Because Raf1 and Cdc25 apparently form a stable association, we determined what fraction of Xenopus Cdc25 protein exists in a complex with Raf1. Extracts prepared from prophase oocytes and progesterone-matured (metaphase II) oocytes were depleted with antiRafl antibodies (see Materials and methods). The initial extracts, depleted extracts, and immunoprecipitates were probed with anti-Rafl (Fig. 1H) or anti-Cdc25 antibodies (Fig. 1I). Under these conditions Rafl kinase was almost fully depleted from extracts with the anti-Rafl antibody. This also resulted in a clear codepletion $(\sim 75 \%)$ of Cdc25. Thus, the majority of the Cdc $25 \mathrm{~mol}-$ ecules in Xenopus oocytes is complexed with Rafl. By comparison, an $80-\mathrm{kD}$ protein, which represented a nonspecific polypeptide that cross-reacts with the Cdc25 antisera on Westem blots did not change in abundance following depletion with Rafl antibody (Fig. 1H). The specificity of the observed interaction was also confirmed by the absence of any significant binding between Rafl and cyclin B/Cdc2 (Fig. 1J).

\section{Raf1/Cdc25 interaction in mammalian cells}

We also investigated whether there might be a physical association between Cdc25 and c-Rafl in mammalian tissue culture cells. Immunoprecipitates were prepared from human HeLa cell lysates using an antibody against the carboxy-terminal peptide of human Cdc25A protein and were blotted with antibodies against Cdc25A or Rafl 
Figure 1. Raf1 and $\mathrm{Cdc} 25$ are associated in Xenopus oocytes. $(A)$ Histone $\mathrm{Hl}$ kinase activity was assayed in anti-cyclin $\mathrm{B} 2 \mathrm{im}$ munoprecipitates from prophase oocytes (lane 1), progesterone-matured oocytes (lane 2), activated eggs (lane 3), cAMPblocked oocytes (lane 4), and IGF-1-matured oocytes (lane 5). Three oocyte equivalents were used per lane. $(B)$ Western blot analysis using an anti-Xenopus $\mathrm{Cdc} 25$ antibody. (Lanes 1-5) Same treatments as in $A$, using six oocyte equivalents per lane. (C) Western blot analysis using an antiRafl antibody. (Lanes 1-5) Same treatments as in $A$, using six oocyte equivalents per lane. (D) Anti-Xenopus Cdc 25 antibody immunoprecipitates were analyzed by Western blot with the same anti-Xenopus Cdc25 antibody. (Lanes 1-5): Same oocyte treatment as in $A$, using 25 oocyte equivalents per lane. $(E)$ Anti-Xenopus Cdc25 antibody immunoprecipitates analyzed by Western blot using the anti-Raf 1 antibody. Eighty oocyte equivalents were used per lane. $(F)$ Anti-Raf 1 antibody immunoprecipitates were analyzed by Western blot (with the same anti-Raf antibody). (Lanes 1-5) Same oocyte treatment as in $A$, using 25 oocyte equivalents per lane. $(G)$ Anti-Rafl antibody immunoprecipitates analyzed by Western blot with the anti-Xenopus Cdc25 antibody (80 oocyte equivalents per lane). $(H)$ Western blot analysis using the anti-Raf antibody. (Lanes $1,3,5\}$ Prophase stage; (lanes 2,4,6) metaphase stage. (Lanes 1,2) Initial extracts, (lanes 3,4) extracts after immunoprecipitation with the anti-Raf antibody; (lanes 5,6) immunoprecipitates with anti-Rafl antibody. (Lanes 1-4) Six oocyte equivalents per lane; (lanes 5,6) 35 oocyte equivalents per lane. (I) Western blot analysis with anti-Xenopus Cde25 antibody of the same samples as in $H$. (Lanes $1-4$ ) Six oocyte equivalents per lane; (lanes 5-6) 160 oocyte equivalents per lane. (/) (Lanes 1-4) Extracts from prophase (lanes 1,2) and metaphase (lanes 3,4$)$ oocytes $\{80$ oocytes per lane) immunoprecipitated with anti-cyclin B2 (lanes 1,3$)$ or anti-Cdc25 $($ lanes 2,4$)$ antibodies and blotted with anti-Rafl antibody.

(Fig. 2A). Reciprocal coimmunoprecipitation of Raf 1 and Cdc25A was detected using both high and low stringency buffers (Fig. 2A,C,D). In each experiment, both Cdc25A and Rafl were detected in the Rafl immune complexes. The specificity of all observed interactions was confirmed by competition with antigenic peptides that eliminated any specific signal from blots performed with anti-Cdc25A or Rafl antibodies (Fig. 2A,C). Immunoprecipitation with antibodies specific to $\mathrm{Cdc} 25 \mathrm{~A}, \mathrm{~B}$, or $C$ proteins indicated that the strongest interaction was between Cdc25A and Rafl (Fig. 2D), but upon longer exposure we could detect some interaction of Rafl and Cdc25B (not shown). We could not find any interaction between Rafl and Cdc25C. Similar experiments were performed in mouse 3T3 cells under conditions optimized for detection of Rafl protein complexes (Freed et al. 1994; Wartmann and Davis 1994). To ascertain what portion of the Cdc25A protein was present in a complex with Rafl, we depleted 3T3 cell extracts with anti-Rafl antibodies in the absence or presence of the Rafl antigenic peptide (Fig. 2B). We found that anti-Rafl antibodies effectively cleared the extracts of Rafl protein (at least $90 \%$ ) and, at the same time, removed a majority
$(60 \%-75 \%)$ of the $67-$ to $72-\mathrm{kD}$ Cdc25A bands with slight preference toward slower migrating forms, indicating that in the extracts of the $3 \mathrm{~T} 3$ cells a majority of the Cdc25A molecules are complexed with Rafl kinase. Reprobing of the same blots with anti-Cdc25C antibodies showed no depletion of the Cdc25C protein (Fig. 2B). Similar results were obtained using the same procedure with extracts prepared from HeLa cells (not shown). A more substantial Rafl/Cdc25A interaction was observed when the extracts were prepared using hypotonic buffer (Freed et al. 1994; Fig. 2, cf. A and B). However, the association of Rafl and Cdc25A was not sensitive to subsequent increase in ionic strengh of the extract /to 300 $\mathrm{mm} \mathrm{NaCl}$ ) or addition of $0.5 \% \mathrm{NP}-40$ (not shown).

\section{Interaction of recombinant Cdc25 and Raf1}

Because Rafl and Cdc25A proteins appeared to interact in cell extracts, we investigated further whether we could reconstruct this association using recombinant proteins expressed in insect cells. We coexpressed human Raf1 kinase (either wild type, a kinase inactive mu$\operatorname{tant}(\mathrm{K} 375 \mathrm{M})$ or an "activated" allele (Y340D) (Fabian et 

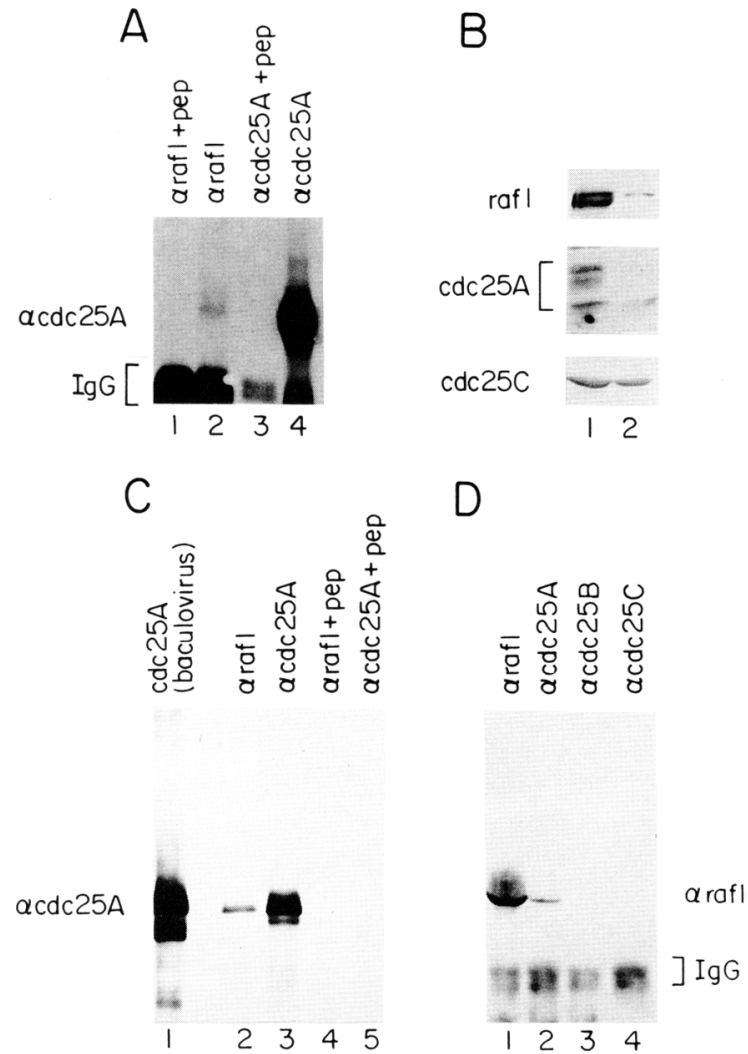

Figure 2. cdc25A associates with Rafl in mammalian cells. $|A|$ Immunoprecipitates of HeLa cell extracts using anti-Raf 1 (lanes 1,2 ) or anti-Cdc25A (lanes 3,4) in the presence (lanes 1,3) or absence (lanes 2,4) of the relevant antigenic peptide were analyzed by SDS-PAGE, followed by immunoblotting with antiCdc25A antibody. (B) Extracts from the 3T3 cells, prepared as described (Freed et al. 1994), with some modifications were depleted with Rafl antibodies in the presence (1) or absence (2) of competening antigenic peptide, analyzed by SDS-PAGE, followed by immunoblotting with anti-Rafl antibody (top), antiCdc25A antibody (middle), or anti-Cdc25C antibody (bottom). (C) Extracts from insect Sf9 cells expressing Cdc25A protein were directly blotted with anti-Cdc25A antibodies (lane 1). HeLa cell extracts (lanes 2-5) were immunopecipitated with anti-Rafl (lanes 2,4) or anti-Cdc25A (lanes 3,5) antibodies in the absence (lanes 2,3) or presence (lanes 4,5 ) of the relevant antigenic peptide, followed by SDS-PAGE and blotting with antiCdc25A antibody. $(D)$ Immunoprecipitates from HeLa cell extracts using anti-Rafl (lane 1), anti-Cdc25A flane 2|, antiCdc25B (lane 3) or anti-Cdc25C (lane 4) antibodies were separated by SDS-PAGE, followed by immunoblotting with anti-Rafl antibody.

al. 1993b) along with human Cdc25A phosphatase (see legend to Fig. 3|. Extracts made from these cells were either directly probed with antibodies against Rafl or Cdc25A (Fig. 3A, top and bottom left) or immunopecipitated with antibodies against $\mathrm{Cdc} 25 \mathrm{~A}$ and then probed with anti-Rafl antibodies (Fig. 3A, top right). We detected a significant interaction between $\mathrm{Cdc} 25 \mathrm{~A}$ and Rafl (Fig. 3A). The extent of binding between Cdc25A and wild-type Rafl kinase, the kinase inactive Rafl $\mathrm{mu}$ - tant and the activated allele of Rafl was found to be similar. Reciprocal experiments using immmunoprecipitations with anti-Raf 1 and blotting with Cdc25A antibodies confirmed the association between $\mathrm{Cdc} 25 \mathrm{~A}$ and Rafl (not shown).

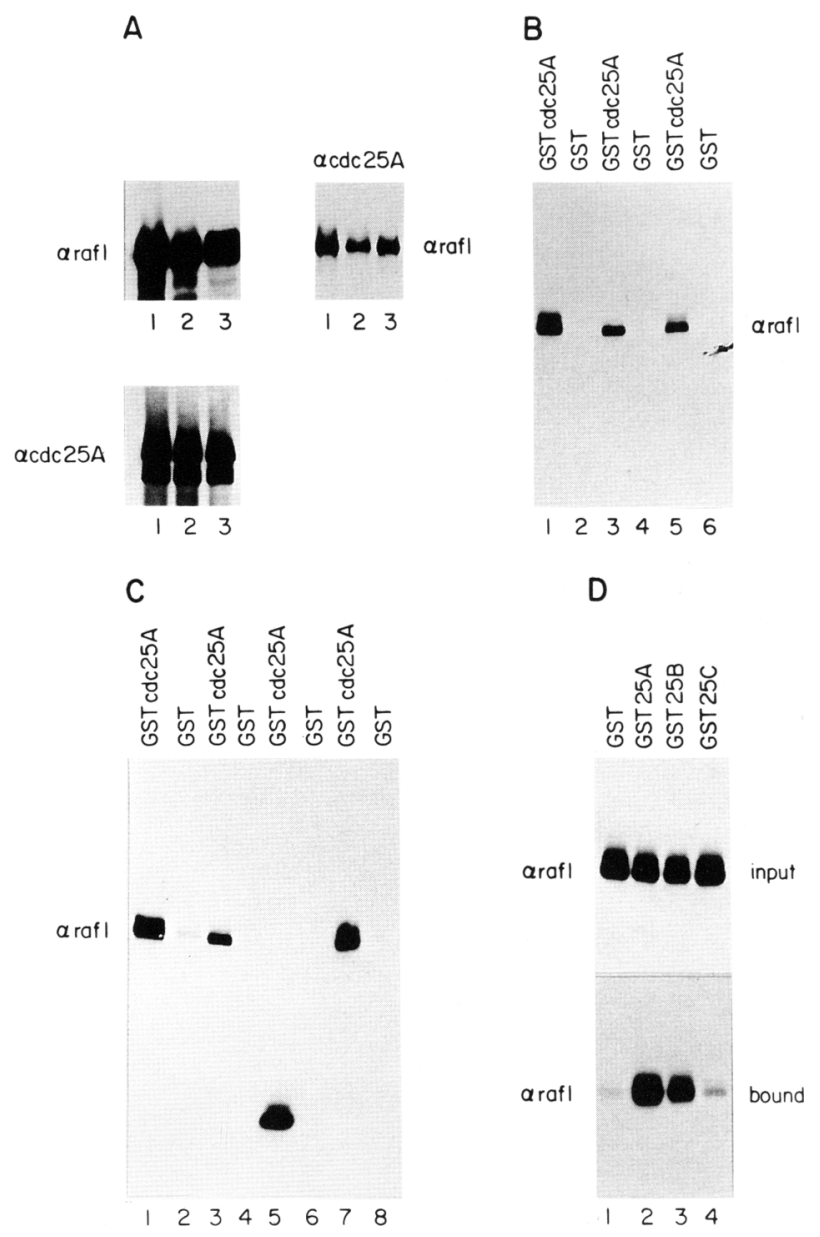

Figure 3. (A) Direct immunoblotting of the extracts from insect Sf9 cells cotransfected with wild-type raf1 (lane 1), kinase inactive mutant (K375M) (lane 2), or "activated" raf1 (Y340D) (lane 3) and $c d c 25 \mathrm{~A}$ baculovirus (lanes 1-3) with anti-Rafl (top left) or anti-Cdc25A antibodies (bottom left). (Right) Immunoprecipitates from the same extracts were made with antiCdc25A antibodies and blotted with anti-Rafl. $(B)$ Extracts from insect cells, expressing wild-type Rafl (lanes 1,2), kinase-inactive mutant (K375M; lanes 3,4), activated Rafl (Y340D, lanes $5,6)$ were incubated with GST or GST-Cdc25A fusion protein and immunoblotted with anti-Rafl antibodies. $(C)$ Experiment similar to $B$. (Lanes 1,2 ) binding to wild-type Rafl as a control; (lanes 3,4) kinase-inactive interfering mutant (K375W); (lanes $5,6)$ truncated Rafl $(22 \mathrm{~W})$; (lanes 7,8$)$ Rafl from cells cotransfected with ras and src viruses (hyperactivated Raf 1 ). Binding of Rafl variants was detected by immunoblotting with anti-Raf 1 antibodies. $(D)$ Association of various human Cdc 25 fusion proteins with wild-type Raf1. (Lane 1) Binding to GST; (lane 2) binding to GST-Cdc25A; (lane 3) binding to GST-Cdc25B; (lane 4) binding to GST-Cdc25C. (Top) Input control. Binding of Raf 1 is assayed by blotting with anti-Rafl antibody. 
We also assayed whether bacterially produced Cdc25glutathione $S$-transferase (GST) fusion protein could form complexes with the Rafl kinase. Extracts prepared from insect cells expressing various forms of Rafl were incubated with GST-Cdc25A or GST alone and then incubated with glutathione-agarose beads. The recovered material was probed with antibodies against Rafl. We observed binding of Cdc25A to the wild-type Rafl, the kinase inactive mutant of Raf1 (both $\mathrm{K} 375 \mathrm{M}$ and interfering $\mathrm{K} 375 \mathrm{~W}$ ), and Rafl kinase activated by coinfection with ras and src baculoviruses (Fig. 3B,C). Interestingly, an amino-terminal deletion of 303 amino acids that produces a hyperactivated Raf 1 kinase $(22 \mathrm{~W}$ ) did not abolish the interaction with Cdc25A (Fig. 3C, lane 5), indicating that Cdc25A can associate with the carboxy-terminal kinase domain of the Rafl protein [(CR3) Rapp et al. 1988].

We also tested the ability of each human Cdc25 protein to interact with Rafl in vitro (Fig. 3D). Equivalent amounts of extracts from cells infected with Rafl baculovirus were incubated with equal amounts of GST, GST-Cdc25A, GST-Cdc25B or GST-Cdc25C proteins (Fig. 3,D). Material recovered on glutathione beads was probed with anti-Rafl antibody. The Rafl kinase preferentially interacted with Cdc25A, to a lesser extent with Cdc25B, and barely with Cdc25C (Fig. 3D), essentially mirroring the results of in vivo analysis.

To test whether the Cdc25/Rafl interaction is direct, we expressed the full-length Raf 1 and amino-terminally truncated Rafl (amino acids 304-648) as GST fusion proteins in bacterial cells and assessed binding of these proteins to bacterially expressed, purified Cdc25A (Fig. $4 \mathrm{~A}, \mathrm{~B}$; see Materials and methods). Strong binding of Cdc25A to full-length or truncated Rafl-GST fusions, but not to GST, was detected (Fig. 4A, bottom). Binding was not sensitive to the presence of $0.5 \%$ NP- 40 or to addition of a carrier protein (BSA), suggesting a strong and specific direct interaction between Raf1 and Cdc25A in vitro.

\section{Raf1-dependent activation of cdc25}

Since we observed in vivo and in vitro interaction between Rafl and Cdc25, we evaluated the potential significance of these phenomena with respect to the phosphatase activity of human Cdc25A. In initial experi-

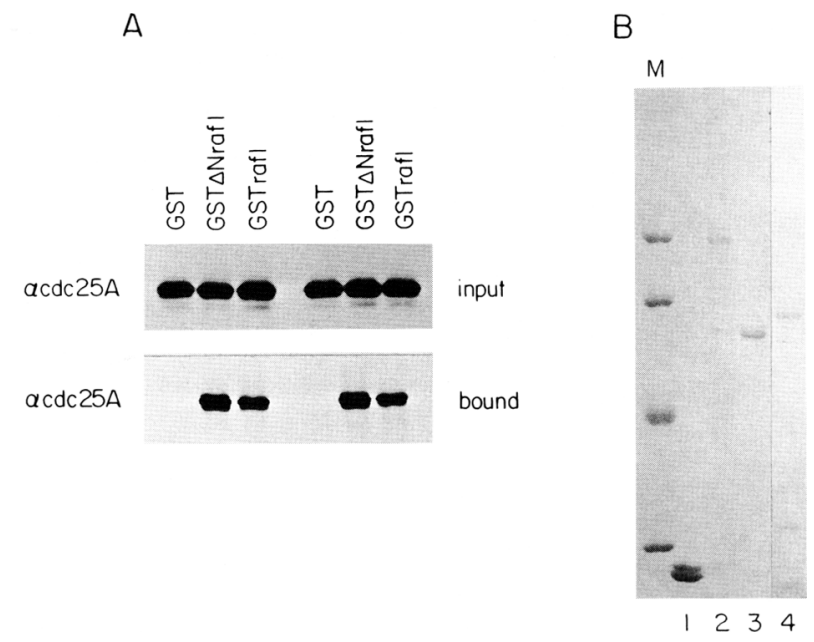

Figure 4. (A) Binding of bacterial Cdc25A to bacterially produced GST-Rafl variants in the absence (left) or presence (right) of the carrier protein (BSA). (B) Coomassie-stained gel showing purified GST (lane 1), GST-Rafl (lane 2), GSTANRaf1 (304-648) (lane 3) and thrombin-cleaved, FPLC-purified Cdc25A (lane 4). Note that thrombin-cleaved, purified Cdc25A runs at $65-66 \mathrm{kD}$ in comparison with $90 \mathrm{kD}$ for GST-Cdc25A fusion protein (Galaktionov and Beach 1991). (Lane M) Low molecular weight markers (Pharmacia), as indicated from the top: phosphorylase $(94 \mathrm{kD}), \mathrm{BSA}(69 \mathrm{kD})$, ovalbumin $(45 \mathrm{kD})$, and carbonic anhydrase $(30 \mathrm{kD})$.

ments, we prepared Rafl immunoprecipitates from HeLa cells or from insect $\mathrm{Sf} 9$ cells coinfected with raf1, ras, and $s r c$ baculoviruses to yield maximally active Rafl $1 \mathrm{ki}$ nase (Williams et al. 1992) and assayed the ability of this kinase to use GST-Cdc25A as a substrate. We observed incorporation of radioactive phosphate into Cdc25A, and this reaction was negated by competition with antigenic Rafl peptide in the initial immunoprecipitation (Fig. 5A). To test the specificity of phosphorylation with respect to different members of the Cde 25 family, we assayed the ability of Rafl immunoprecipitates from HeLa cells to phosphorylate equal amounts of GST, GSTCdc25A, GST-Cdc25B, and GST-Cdc25C. Phosphorylation of the Cdc25A fusion protein was strongest (Fig. 5B),

Figure 5. Phosphorylation and activation of Cdc25 by Rafl immuno- and protein complexes. $(A)$ Immunoprecipitates from HeLa (lanes 1,2 ) or Sf9 cells triply transfected with raf1, ras, and $\operatorname{src}$ (lanes 3,4 ) performed in the absence $($ lanes 1,4$)$ or presence of Raf 1 antigenic peptide were incubated with GST-Cdc25A in a kinase buffer with $\left[\gamma^{-32}\right.$ P $]$ ATP, followed by SDS-PAGE. (B) Immunoprecipitates from HeLa cells were incubated with GST (lane 1), GST-Cdc25A (lane 2), GST-Cdc25B (lane 3), GST-Cdc25C (lane 4) (using the same condiditions as in $A$ ), followed by SDS-PAGE. (C) Time course of the phosphatase reaction using paranitrophenylphosphate (PNPP) as a substrate was followed with Cdc25A preincubated with mock control (extract prepared from Sf9 cells infected with a wild-type baculovirus) and hyperactive Rafl (22W). (D) GST-Cdc25A phosphatase activity against PNPP was measured after incubation with mock control (1), Raf 1 in the absence (2) or presence of ATP (3), or kinase inactive mutant of Raf 1 (4). Experiments were done in triplicate. Error bars show two standard deviations from the mean. $(E)$ Phosphatase activity of Cdc25A against tyrosine-phosphorylated inactive cyclin $\mathrm{A} / \mathrm{cdk} 2$ kinase was measured using histone $\mathrm{Hl}$ as a substrate. Each point (from 1 to 4 ) correspond to threefold increase in amount of added Cdc25 with the same amount of substrate (largely inactive cyclin A/cdk2). Hatched bars correspond to control Cdc25; solid bars correspond to Cdc25 activated by Rafl complexes. 
followed by phosphorylation of Cdc25B. The Cdc25C protein was phosphorylated at least 100 times less effi- ciently than Cdc25A, and no phosphorylation of GST was detected.
A

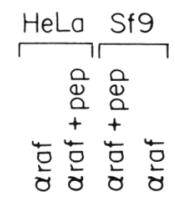

GST

cdc25A

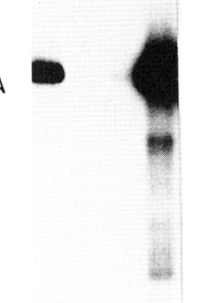

1234
B

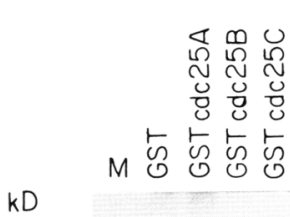

$94-$

$67-$

$45-$

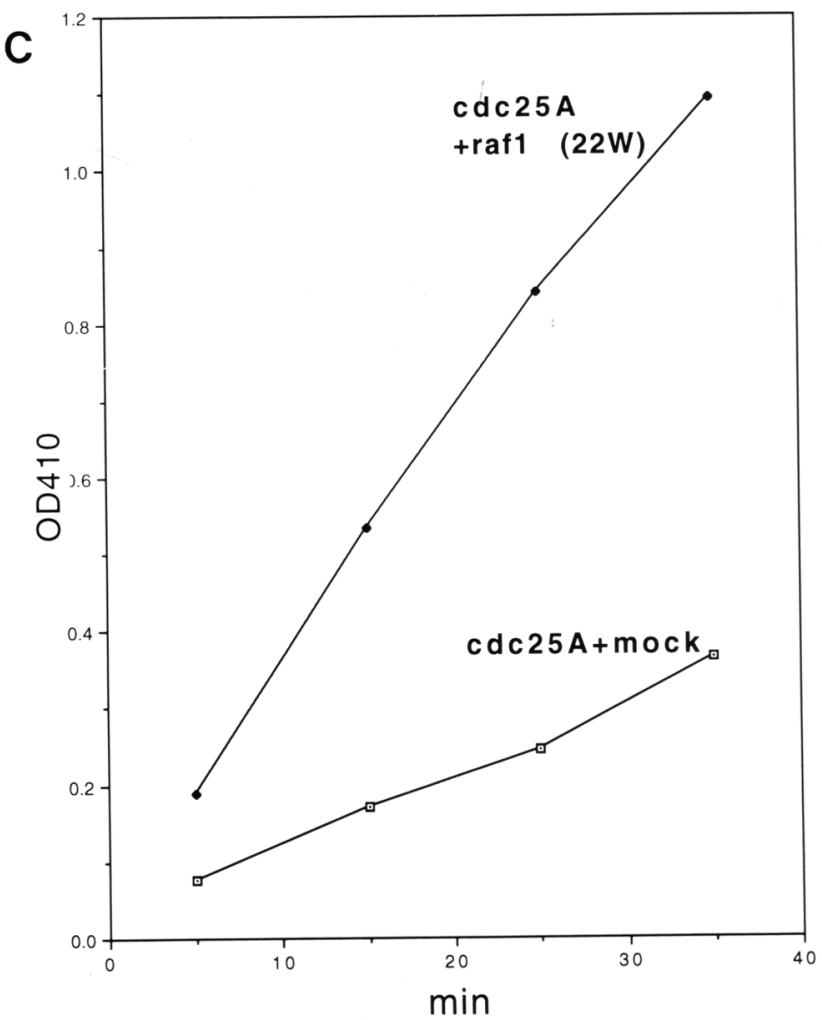

D
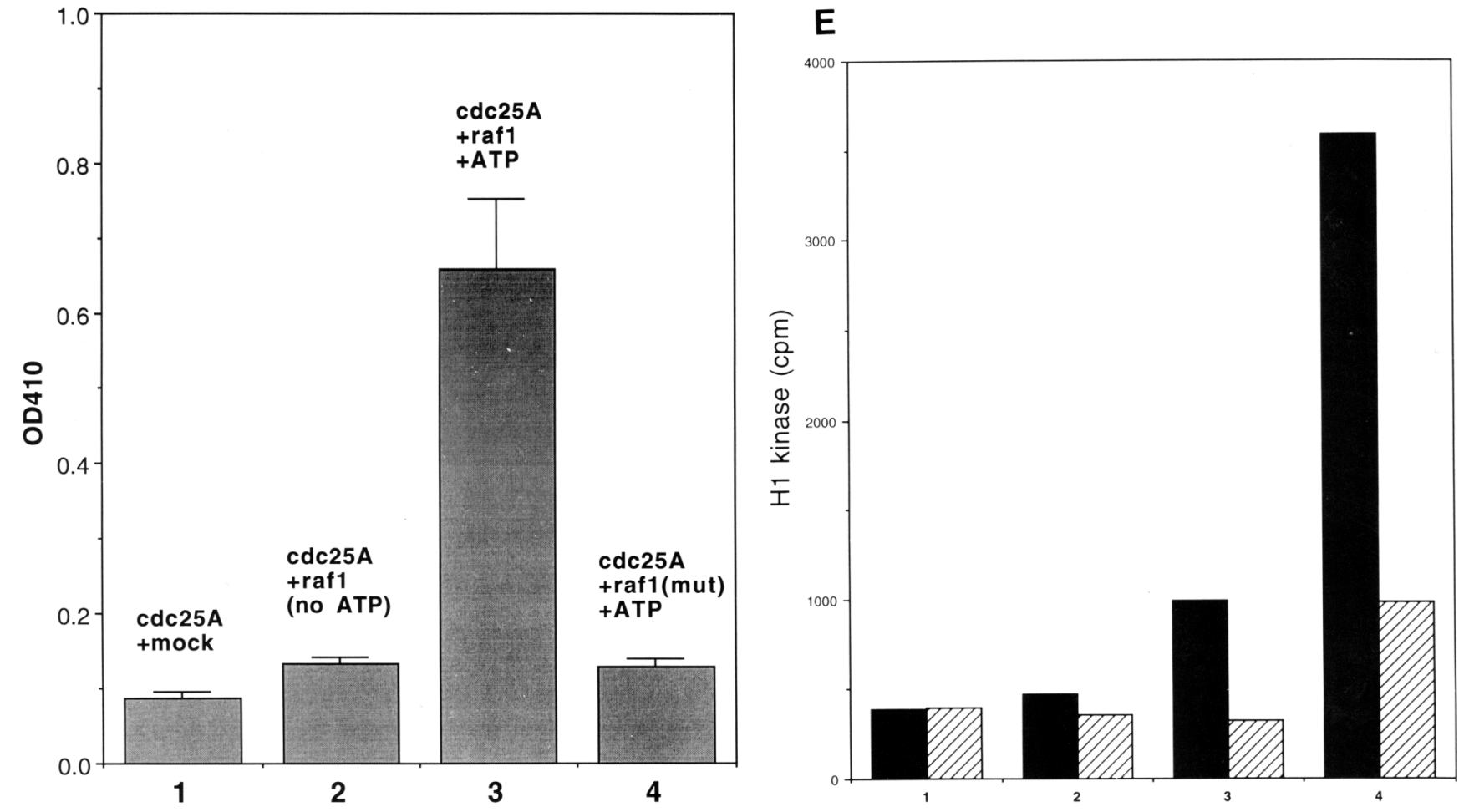

Figure 5. (See facing page for legend.) 
To assess the effect of phosphorylation of Cdc25A on its intrinsic phosphatase activity we incubated GSTCdc25A or GST with cell extracts from Sf9 cells infected with various baculoviruses, including wild-type and mutant Rafl (see legend to Fig. 5; Materials and methods). After incubation with glutathione-agarose beads the resulting complexes were washed, retaining Rafl kinase associated with Cdc25A. Complexes were then incubated in kinase buffer (in the presence or absence of ATP). Thereafter, ATP was washed away and Cdc25 phosphatase activity was measured using paranitrophenylphosphate (PNPP), a synthetic substrate that is structurally similar to phosphotyrosine (Dunphy and Kumagai 1991; Galaktionov and Beach 1991). Experiments described above were done using either hyperactive raf1 (22W; Fig. 5C), or raf1 kinase activated by cotransfection with ras and src (Fig. 5D,E). A three- to fourfold increase in Cdc25A phosphatase activity was detected (Fig. 5D,E). Activation was dependent on the addition of ATP and was negligible with a kinase-inactive (K375M) raf1 mutant (Fig. 5D, lane 4). Similar activation of Cdc25A phosphatase activity was seen using a Cdc 25 assay that measured dephosphorylation and activation of GST-cyclin $\mathrm{A} / \mathrm{cdk} 2$ (inhibited in vitro by Weel kinase; see legend to Fig. 5; Fig. 5E). In both experiments a three- to fourfold activation of Cdc25 phosphatase activity was observed (Fig. 5C-E). We have been unable to determine the sites of Raf1-dependent phosphorylation on Cdc25A, as the amount of ${ }^{32} \mathrm{P}$-labeled $\mathrm{Cdc} 25 \mathrm{~A}$ produced in vivo in unsynchronized $3 \mathrm{~T} 3$ or HeLa cells was insufficient for mapping purposes.

\section{Membrane colocalization of Cdc25 with Ras and Raf1}

It has been shown previously that some fraction of Rafl and Ras colocalize in the cell membrane (Traverse et al. 1993). Colocalization was enhanced in cells transformed with oncogenic Ras and was abolished in cells transformed with interfering Ras mutants (Leevers et al. 1994; Stokoe et al. 1994). To test whether Cdc25 might also colocalize with Ras and Rafl, we took advantage of mouse fibroblasts stably transfected with oncogenic Haras (V12) and $c d c 25 A$ (see Materials and methods). Cells were stained with monoclonal antibodies against Ras or Rafl and with affinity-purified polyclonal antibodies against Cdc25A or Cdc25B. As expected, we could detect cytoplasmic and membrane staining with both anti-Rafl and anti-Ras antibodies (Fig. 6B,D,F). We could also clearly observe membrane staining with both anti$\mathrm{Cdc} 25 \mathrm{~A}$ and $-\mathrm{Cdc} 25 \mathrm{~B}$ antibodies (Fig. 6A,C,E). Using double immunofluorescence, we observed significant colocalization of Ras or Raf1 and Cdc25 at the cell membrane (Fig. 6, arrows). Areas of cellular membrane "ruffles," representing the moving edge of the cell, were stained most prominently with anti-Cdc25A and -Cdc25B antibodies, as well as anti-Ras and anti-Rafl antibodies. Both anti-Cdc 25 antibodies also stain the nucleus; however, nuclear staining was not observed with anti-Rafl and anti-Ras antibodies. Some immunofluorescence with anti-Cdc25A antibodies was found in cyto- plasmic "dots" and anti-Cdc25B-stained cytoskeletal structures (Fig. 6A,C,E). Preincubation of antibodies with antigenic peptides abolished all staining observed with anti-Cdc25A and anti-Cdc25B antibodies (Fig. 6G,H).

To extend our observations on Cdc25/Rafl colocalization, we fractionated 3T3 and mouse fibroblast cells into nuclear, S100, and P100 fractions (Freed et al. 1994; Leevers et al. 1994; Wartmann and Davis 1994). These were directly blotted with anti-Rafl or anti-Cdc25A antibodies. As expected, Rafl localized to S100 and P100 fractions with very little in the nuclear fraction, whereas Cdc25A was found in all three fractions (Fig. 6I). The Cdc25A present in $\mathrm{S} 100$ fraction was readily immunoprecipitated by anti-Cdc25A antibodies (Fig. 6I, middle) which also brought down Rafl in a complex (Fig. 6I, bottom). Following serum stimulation Cdc25A associates exclusively with the phosphorylated (upshifted) species of Rafl (Fig. 6I, bottom). The nuclear and membranebound Cdc25A (fractions $\mathrm{N}$ and P100) was not extracted by $1 \%$ NP-40 (Fig. 6I), suggesting a tight association with cytoskeleton and/or nuclear matrix structures. We estimate, after correcting for the protein content of the $\mathrm{S} 100$, $\mathrm{P} 100$, and nuclear fractions, that $5 \%-10 \%$ of $\mathrm{Cdc} 25 \mathrm{~A}$ is associated with the membrane/cytoskeletal fraction (P100), 40\%-50\% is cytoplasmic, and $\sim 40 \%-50 \%$ is nuclear.

\section{Discussion}

The existence of a link between mitogenic signal transduction and the cell cycle machinery has long been anticipated. Previous work has shown that D-type cyclins are induced in response to growth factor stimulation (Matsushime et al. 1991; Won et al. 1992). Induction of the D-type cyclins, however, corresponds in time to passage through restriction point (Rossow et al. 1979; for review, see Pines and Hunter 1994; Sherr 1994), representing a downstream effect of the signal transduction cascade. The results presented here suggest that one aspect of a link between signal tranduction and cell cycle is surprisingly direct. We demonstrate that Rafl kinase forms complexes with a cell cycle activator, the Cdc25 phosphatase. This interaction was observed in human and mouse somatic cells and in frog oocytes. Furthermore, bacterially produced human Cdc $25 \mathrm{~A}$ could associate with recombinant Rafl produced in insect cells. The association of Rafl and Cdc25A involves the carboxy-terminal CR3 (kinase) domain of the Raf1 protein, a region that is indispensable for Rafl-transforming activity (Stanton et al. 1989; Heidecker et al. 1990). Raf1 and Cdc25 A expressed in bacteria also bind in vitro, suggesting a direct protein-protein interaction.

We observed interaction of Rafl with human Cdc25A and, to some extent, with Cdc25B but not with Cdc25C. Rafl also associates with Xenopus Cdc25, which has been classified as a C-type Cdc25 phosphatase (Kumagai and Dunphy 1992). However, human Cdc25C is 80 amino acids shorter than Xenopus Cdc25 and shares 

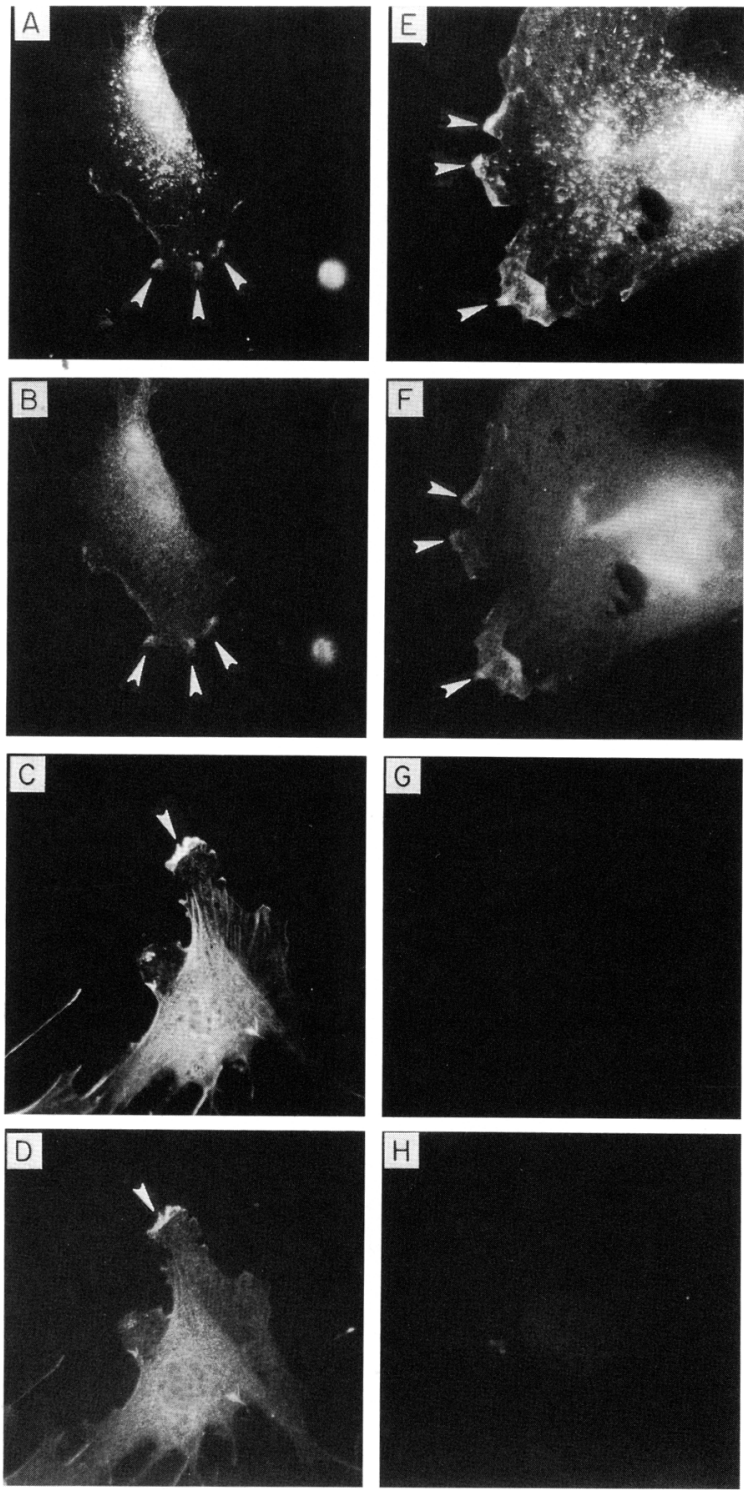

I
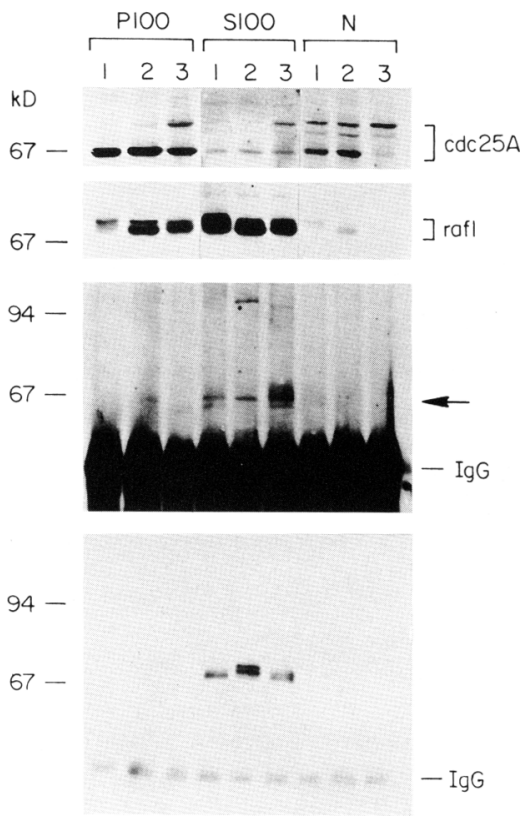

Figure 6. Colocalization of Cdc25A, Cdc25B, Ras, and Rafl at the cell membrane by immunofluorescence staining and subcellular fractionation. $(A-H)$ Immunofluorescent staining of mouse fibroblasts with anti-Cdc25A $(A, E)$, anti-Cdc25B $(c), \operatorname{Ras}(B, D)$, Raf1 $(f)$ and anti-Cdc25A $(G)$ or anti-Cdc25B $(H)$, preincubated with competing antigenic peptide. (I) Direct blot of the 3T3 cell fractions with anti-Cdc25A or anti-Rafl antibodics (top two panels) or immunoprecipitation of the extracted material with anti-Cdc25A antibodies followed by detection with antiCdc25A (middle) or anti-Rafl antibodies (bottom). (Lanes 1) Quiescent 3 T3 cells; (lanes 2) serum-stimulated 3T3 cells; (lanes 3) mouse fibroblasts transfected with Cdc25A and Ras. rather limited homology to it (Galaktionov and Beach 1991; Kumagai and Dunphy 1992), complicating classification of the known Xenopus enzyme with respect to the human proteins.

The significance of the Raf $1 / \mathrm{Cdc} 25$ interaction is suggested by the fact that Cdc 25 can serve as a substrate of the Rafl kinase in vitro. The ability of Rafl immunocomplexes to phosphorylate different human Cdc25 proteins correlates with their Rafl-binding properties. This has also been shown for MEK (van Aelst et al. 1993), a previously described physiological substrate of Rafl (Dent et al. 1992; Howe et al. 1992; Kyriakis et al. 1992). Rafl-dependent phosphorylation of Cde $25 \mathrm{~A}$ is associated with activation of $\mathrm{Cdc} 25 \mathrm{~A}$ phosphatase activity. One explanation for our results is that Cdc25A is phosphorylated directly by Raf1. However, our findings are also consistent with the possibility that a Rafl-dependent kinase, present in the same protein complex, phosphory- lates Cdc25. One candidate is MEK, but we cannot exclude that another uncharacterized kinase that is present both in HeLa and Sf9 cells binds to Rafl and phosphorylates Cdc 25 proteins in a Rafl-dependent manner.

Physical and functional interaction of Cdc25 with Rafl was initially surprising, as membrane translocation of Rafl has been recently shown to be important for its activation (Leevers et al. 1994; Stokoe et al. 1994). However, using double immunofluorescence microscopy, we have shown that Ras and Rafl colocalize in part with Cdc25A and Cdc25B at the cell membrane. Biochemical fractionation further supported immunofluorescence data. It has been shown that in HeLa cells Cdc25A is largely nuclear and is phosphorylated at the $G_{1} / S$ border presumably by the cyclin E/Cdk2 kinase (Hoffman et al. 1994). Our data on the localization of the Cdc25A in mammalian cells show that although Cdc25A is partially localized to the nucleus in $3 \mathrm{~T} 3$ cells, we can also 
detect cytoplasmic and presumably membrane- or cytoskeleton-bound Cdc25A. Because Cdc25A is phosphorylated by Rafl complexes in vitro and is associated with upshifted (activated) Rafl shortly after serum stimulation (Fig. 6I), we believe that it may be phosphorylated and activated earlier in the cell cycle than $\mathrm{G}_{1} / \mathrm{S}$ border. It is possible, however, that both suggestions are correct and that Cdc25A has functions in several points in the cell cycle. Both Cdc25A and Cdc25B have been shown to dephosphorylate and activate cdc2 and cdk2; however, it is possible that cdks are not the only substrates of Cdc25 phosphatases. It is unlikely that Rafl phosphoprotein itself is such a substrate, since dephosphorylation of active, phosphorylated Rafl was not observed during incubation with Cdc25A phosphatase in vitro.

Our results suggest that direct physical interaction of Cdc25 and Raf1 may play a key role in activation of the cell cycle in response to mitogens. However, ras and Rafl almost certainly control mitogenic response to extracellular stimuli via multiple pathways (Herskowitz 1995; Marshall 1995). For example, Ras is required for the Raf/MEK/ERK pathway, for PI3-kinase activation (Rodriguez-Viciana et al. 1994) and for a MEKK-1/SEK1/JNK(SAPK) kinase pathway (Hibi et al. 1993; LangeCarter and Johnson 1994; Minden et al. 1994; Sanchez et al. 1994; Yan et al. 1994) induced in response to osmotic shock, UV irradiation, and cytokines (for review, see Marshall 1995). In 3T3 cells, activated MEK, which does not require Rafl, causes induction of DNA replication and oncogenic transformation in parallel with MAP kinase activation (Cowley et al. 1994). Alternatively, in Rat 1 cells, Ras and activated Rafl cause oncogenic transformation without constitutively activating MEK and MAP kinases (ERKs), further underlying emerging complexity of the signal transduction pathways.

The Rafl kinase is also an essential element of meiotic maturation, where it has been shown to function downstream of Mos, possibly activating MEK (Muslin et al. 1993). The downstream target of MEK, MAP kinase, is not, however, involved in the maturation of Xenopus oocytes but, instead, displays cytostatic factor (CSF) activity (Haccard et al. 1993), posing an apparent paradox for interpretation of the role of Rafl in meiosis. As a resolution to this paradox we propose that at the level of Rafl or MEK Ras/Rafl signal transduction pathways bifurcate with at least two major downstream targets: MAP kinases and Cdc25 cell cycle phosphatases. Activation of Cdc 25 by the Ras/Rafl pathway is proposed to lead to cell cycle stimulation.

Stimulation of Raf1 by Ras is certainly a major event in Ras-mediated signal transduction, but because Ras has been shown to directly activate phosphatidylinositol-3 kinase activity (Rodriguez-Viciana et al. 1994), it is possible that inositol metabolites and, perhaps, protein kinase $\mathrm{C}$ are involved in an additional pathway that leads to the activation of $\mathrm{Cdc} 25$ or other cell cycle components after mitogenic stimuli. The possible involvement of the newly discovered Ras/MEKK-1/SEK1/INK(SAPK) pathway in the activation of Cdc25 awaits further investigation.
It may seem paradoxical that $\mathrm{Cdc} 25$ is apparently involved in the signal transduction pathways. To date, Cdc25 proteins have been shown to activate Cdc2 and Cdk2; however, the possibility remains that other cdks, namely cdk 4 and cdk6, that function in $G_{1}$ could be under some Weel/Cdc25 control because they both contain the evolutionarily conserved Tyr residue in the nucleotide-binding domain. Activation of the Cdc25A by Ras/Rafl signal transduction pathway could ensure that all cdk/cyclin complexes in $G_{1}$ are active in the presence of growth factors and that their activity depends only on the balance of relevant cyclins/cdks and cdk inhibitors (pending continuous presence of the active cdk-activating kinase). Withdrawal of the growth factors in $G_{1}$ preceding the restriction point (Rossow et al. 1979) could abort the cell cycle via rapid inactivation of Cdc25. In possible agreement with this hypothesis it has been shown that Cdc25A is essential in $G_{1}$ (Jinno et al. 1994).

In summary, the results presented here constitute a direct link between cell cycle control and mitogenic signal transduction pathways in higher eukaryotes and establish Cdc25 phosphatases as key molecules in this process.

\section{Materials and methods}

Oocytes

Xenopus leavis prophase oocytes were prepared as described previously (Jessus et al. 1987; Jessus and Beach 1992). Progesterone-induced meiotic maturation and egg activation were performed as described in Jessus and Beach (1992), and IGF-1-induced meiotic maturation as described in Sadler and Maller (1989). cAMP-blocked oocytes were pretreated for $1 \mathrm{hr}$ with 1 mM IBMX and $0.1 \mu \mathrm{g} / \mathrm{ml}$ of cholera toxin before adding progesterone. Oocytes were rinsed extensively in extraction buffer ((EB) $80 \mathrm{~mm} \beta$-glycerophosphate, $20 \mathrm{~mm}$ EGTA, $15 \mathrm{mM} \mathrm{MgCl}_{2}$, $1 \mathrm{mM}$ DTT, $25 \mathrm{mM} \mathrm{NaF}$, and $1 \mathrm{~mm}$ orthovanadatel and lysed in 5 volumes of EB with protease inhibitors $(1 \mathrm{mM}$ PMSF, $25 \mu \mathrm{g} / \mathrm{ml}$ of leupeptin, $25 \mu \mathrm{g} / \mathrm{ml}$ of aprotinin, $1 \mathrm{~mm}$ benzamidine, $10 \mu \mathrm{g} /$ $\mathrm{ml}$ of $N$ - $\alpha$-tosyl-L-lysine chloromethyl ketone (TLCK) and 70 $\mu \mathrm{g} / \mathrm{ml}$ of tosyl-L-phenylalanine chloromethyl ketone (TPCK). Insoluble material and lipids were separated by centrifugation at $13,000 \mathrm{~g}$ for $15 \mathrm{~min}$ at $4^{\circ} \mathrm{C}$, and the supernatant was used for immunoprecipitations and Western blot analysis. Nitrocellulose filters were incubated for $4 \mathrm{hr}$ with primary antibody diluted in $1 \%$ milk-TBS with $0.1 \%$ Tween 20 (TBST). The antiRafl carboxy-terminal antipeptide antibody (C-20, Santa Cruz Biotechnology) and the anti-Xenopus Cdc25 antibody (described in Kumagai and Dunphy 1992; gift of Dr. W. Dunphy/ were used at concentrations of $10 \mu \mathrm{g} / 10 \mathrm{ml}$, and $2.5 \mu \mathrm{g} / 10 \mathrm{ml}$, respectively. After washing, filters were incubated for $1 \mathrm{hr}$ with HRPcoupled protein A (GIBCO) at a 1:5000 dilution in $1 \%$ milkTBST and developed using enhanced chemiluminescence (ECL) (Amersham). Immunoprecipitations were performed by incubating oocyte lysates with the anti-Raf 1 antibody $11 \mu \mathrm{g}$ of C-20, Santa Cruz Biotechnologyl, with an anti-Xenopus Cdc25 antibody [1:100 dilution (described in Izumi et al. 1992; gift of Dr. J. Maller)] or with anti-cyclin B2 antibody (described in Izumi and Maller 1991; gift of Dr. J. Maller) for $4 \mathrm{hr}$ at $4^{\circ} \mathrm{C}$. Protein A-Sepharose beads were used to collect the immune complexes. To estimate $\mathrm{Cdc} 2$ histone $\mathrm{Hl}$ kinase activity, immunoprecipitations were performed with an anti-Xenopus cyclin B2 antibody [dilution 1:100/described in Izumi and Maller 1991; 
gift of Dr. J. Maller)] for $1 \mathrm{hr}$ at $4^{\circ} \mathrm{C}$. Protein G-Sepharose beads were used to collect the immune complexes; these were washed with kinase buffer (Jessus and Beach 1992) and assayed for histone H1 kinase activity (Jessus and Beach 1992).

\section{Mammalian cells}

HeLa cells grown in suspension were obtained from Cold Spring Harbor Laboratory Tissue Culture Facility and used at the cell density of $0.5 \times 10^{6}$ to $0.8 \times 10^{6}$ cells $/ \mathrm{ml}$. Cells were centrifuged for $10 \mathrm{~min}$ at $1000 \mathrm{~g}$, washed with PBS three times, and lysed in 5 volumes of the lysis buffer. In some experiments (Fig. $2 \mathrm{~A}, \mathrm{C}$ ) a standard buffer was used (Xiong et al. 1993). In other experiments $(B, D)$ we used low ionic strength buffer with $1 \%$ NP-40 (D) or without it (B) (Freed et al. 1994; Wartmann and Davis 1994). 3T3 cell fractionation was performed essentially as described (Freed et al. 1994; Stokoe et al. 1994; Wartmann and Davis 1994], using hypotonic buffer [ $10 \mathrm{~mm}$ Tris- $\mathrm{HCl}$ at $\mathrm{pH} 7.5$, $5 \mathrm{~mm} \mathrm{MgCl}_{2} ; 25 \mathrm{~mm} \mathrm{NaF}, 1 \mathrm{~mm}$ EGTA, $1 \mathrm{~mm}$ orthovanadate, supplemented with aprotinin $(10 \mu \mathrm{g} / \mathrm{ml})$, leupeptin $(10 \mu \mathrm{g} / \mathrm{ml})$, soybean trypsin inhibitor $(20 \mu \mathrm{g} / \mathrm{ml})$, pepstatin $(1 \mu \mathrm{g} / \mathrm{ml})$, and $0.5 \mathrm{~mm}$ phenylmethylsulfonyl fluoride (PMSF)] for cell lysis as described in Freed et al. (1994) and buffer A $[20 \mathrm{~mm}$ Tris- $\mathrm{HCl}$ (pH 7.4), $137 \mathrm{~mm} \mathrm{NaCl}, 2 \mathrm{~mm}$ EDTA, $2 \mathrm{~mm}$ sodium pyrophosphate, $25 \mathrm{~mm} \beta$-glycerophosphate, and $10 \%$ glycerol, supplemented with PMSF $(0.5 \mathrm{~mm})$, leupeptin $(10 \mu \mathrm{g} / \mathrm{ml})$ and aprotinin (10 $\mu \mathrm{g} / \mathrm{ml})$, Wartmann and Davis 1994)] with $1 \%$ NP-40 for extraction of the membrane and nuclear fraction from confluent quiescent $3 \mathrm{~T} 3$ cells before or after $15 \mathrm{~min}$ of stimulation with $10 \%$ calf serum. The same procedure was applied to unsynchronized mouse fibroblasts, cotransfected with RcCMV-cdc25A and Ha-ras (Val12) in pNV, obtained from Dr. D. Bar-Sagi (Cold Spring Harbor Laboratory). Immunoprecipitation from S100 fraction was optimal for detecting Cdc25A/Raf 1 interaction in all mammalian cell lines tested. Equal amounts $(50 \mu \mathrm{g})$ of proteins were loaded in each lanc. Antibodies were raised against a peptide representing the eight carboxy-terminal residues of Cdc25A (CMYSRLKKL), and another, representing seven carboxy-terminal amino acids of Cdc25B (CSRLQDQ). Both peptides were cross-linked with keyhole limpet hemocyanin (KLH) and used to immunize rabbits. Antiserum was collected and affinity purified using the peptides cross-linked with SulphoLink beads (Pierce). GST-fusions with Cdc25A, Cdc25B, and $\mathrm{Cdc} 25 \mathrm{C}$ were described previously /Galaktionov and Beach 1991). Proteins were purified as described (Galaktionov and Beach 1991) with some modifications and used to immunize rabbits. Antisera against GST fusions were depleted extensively on GST-Sepharose beads followed by Sepharose beads with nonspecific Cdc25 fusion (we used GST Cdc25B to remove cross-reacting species from anti-Cdc25A antibodies and vice versa). Finally, specific antibodies were affinity purified using the relevant fusion protein attached to the Sepharose beads. We routinely used carboxy-terminal peptide antibodies for immunoprecipitation, followed by Western blotting with affinitypurified antibodies against the full-length protein. No crossreactivities were detected between any of the affinity-purified antibodies against $\mathrm{Cdc} 25 \mathrm{~A}, \mathrm{Cdc} 25 \mathrm{~B}$, and $\mathrm{Cdc} 25 \mathrm{C}$ (both carboxyterminal and full length). Antibodies against the carboxyl terminus of Cdc25C were described previously (Hoffmann et al. 1993) and kindly provided to us by Dr. G. Draetta (Mitotix) or purchased from Santa Cruz Biotechnology. Antibodies against Raf 1 (C20) were purchased from Santa Cruz Biotechnology. All antibodies were used at $0.5-1 \mu \mathrm{g}$ per immunoprecipitation (except for Fig. 2A, lanes 1 and 2, where $5 \mu$ g was used). Antibodies were typically incubated with cell extracts for $4-6 \mathrm{hr}$, followed by a $\mathrm{l} \mathrm{hr}$ incubation with protein $\mathrm{A}$ or protein $\mathrm{G}$ beads (Pierce,
Pharmacia). Immunoprecipitates were recovered by low speed centrifugation and washed four to five times in the lysis buffer. Samples for $8.5 \%$ SDS-PAGE were prepared by treatment of the recovered immune complexes with sample buffer at $95^{\circ} \mathrm{C}$ for 5-10 min as described (Laemmli 1970). Immunoblotting analysis was performed as described. Positive signals were detected using protein A-horseradish peroxidase (HRP) (at 1:2000 dilution) and ECL (Amersham) according to instructions provided by the manufacturer.

\section{Insect cells}

Spodoptera frugiperda $(\mathrm{Sf} 9)$ cells grown in monolayer were infected at $5 \times$ multiplicity with recombinant baculoviruses encoding Cdc25A alone or in a combination with viruses encoding wild-type Rafl, kinase inactive Rafl (K375M or K375W), truncated Rafl (22W) or "activated" rafl (Y340D) (Fabian et al. 1993b; Williams et al. 1993). In some cases, triple infection with raf1, ras, and src baculoviruses was performed as described (Williams et al. 1992). At 60-72 hr postinfection, cells grown on 100- or 150-mm plates were washed with PBS, scraped from the plates, washed two more times in PBS, and lysed in kinase buffer (KB), containing $25 \mathrm{mM}$ HEPES (pH 7.4), $150 \mathrm{mM} \mathrm{NaCl}, 25$ mM $\beta$-glycerophosphate, $10 \mathrm{~mm} \mathrm{MgCl}_{2}, 0.1 \mathrm{~mm}$ EDTA, $5 \mathrm{~mm}$ EGTA, supplemented with $1 \mathrm{~mm}$ DTT, $1 \mathrm{~mm}$ orthovanadate, 10 $\mu \mathrm{g} / \mathrm{ml}$ of aprotinin, $10 \mu \mathrm{g} / \mathrm{ml}$ of leupeptin, $0.5 \mu \mathrm{g} / \mathrm{ml}$ of pepstatin, $1 \mu \mathrm{g} / \mathrm{ml}$ chymostatin, $1 \mathrm{~mm}$ benzamidine, $0.5 \mathrm{~mm}$ PMSF. Cells were disrupted by passing six times through a $26^{1 / 2}$-gauge needle. Extracts were cleared by centrifugation twice at $15,000 \mathrm{~g}$ for $15 \mathrm{~min}$ each. Cleared lysates were supplemented with glycerol to $20 \%$ and stored frozen at $-70^{\circ} \mathrm{C}$ in aliquots. Immunoprecipitations were performed as described in the legend to Figure 1. GST-fusion proteins and GST were purified as described (Galaktionov and Beach 1991) on glutathione-Sepharose columns (Pharmacia) and eluted with $10 \mathrm{~mm}$ glutathione in GT buffer $150 \mathrm{~mm}$ Tris- $\mathrm{HCl}$ at $\mathrm{pH} 8.0,200 \mathrm{~mm} \mathrm{NaCl}, 1 \mathrm{~mm}$ EDTA, $10 \%$ glycerol, $1 \mathrm{~mm}$ DTT, supplemented with $0.5 \mathrm{mM}$ PMSF, 1 $\mathrm{mm}$ benzamidine, $10 \mu \mathrm{g} / \mathrm{ml}$ of leupeptin, and $10 \mu \mathrm{g} / \mathrm{ml}$ of aprotinin. GST or GST-fusion proteins were diluted at least 10-fold in $\mathrm{KB}$, mixed with insect cell extracts /typically $2 \mu \mathrm{g}$ of the GST fusion and 20-50 $\mu$ l of the extract), and incubated on ice for 2-4 hr. Glutathione-agarose beads, equilibrated in $\mathrm{KB}$ buffer, were added $(30 \mu \mathrm{l}$ of a $1: 1$ slurry $)$, rotated at $4^{\circ} \mathrm{C}$ for $1 \mathrm{hr}$ and washed four to five times in KB. Samples were separated by $8.5 \%$ SDSPAGE, electrotransferred onto nitrocellulose, and probed with anti-Rafl antibodies $(0.2 \mu \mathrm{g} / \mathrm{ml})$, followed by protein A-HRP (1:2000-1:5000; Amersham). Positive signals were detected using ECL (Amersham).

\section{Bacterial proteins}

To purify bacterial Cdc25A protein, GST-Cdc25A /Galaktionov and Beach 1991) was digested with thrombin. Cdc25A, GSTRafl and GST $\Delta$ NRafl (amino acids 304-648) were purified on FPLC (mono Q) and checked by $10 \%$ PAGE (Fig. 4). Proteins (1 $\mu \mathrm{g}$ each) were mixed in $50 \mu \mathrm{l}$ of $50 \mathrm{~mm}$ Tris- $\mathrm{HCl}(\mathrm{pH} 8.0), 150$ $\mathrm{mm} \mathrm{NaCl}$ with $10 \mu \mathrm{l}$ of glutathione-agarose beads /with or without $5 \mathrm{mg} / \mu \mathrm{l}$ of $\mathrm{BSA}$ ), incubated for $1 \mathrm{hr}$ at $4^{\circ} \mathrm{C}$, and washed four times with the same buffer with $0.5 \%$ NP- 40 . Samples were analyzed further by immunoblotting with anti-Cdc25A as described above.

\section{Kinase reactions}

Immunoprecipitates of HeLa cell extracts with anti-Rafl antibodies were done under standard conditions (Xiong et al. 1993). In some cases, antigenic peptide was added at $2-3 \mu \mathrm{g} / \mu \mathrm{g}$ of 
antibody. Immunoprecipitates were washed twice in KB buffer, and 1-2 $\mu \mathrm{g}$ of GST or GST-fusion proteins was added. Reactions were supplemented with $50 \mu \mathrm{M}$ ATP, $10 \mu \mathrm{Ci}$ of $\left[\gamma^{-32} \mathrm{P}\right] \mathrm{ATP}$, incubated at $30^{\circ} \mathrm{C}$ for $10 \mathrm{~min}$, and terminated by the addition of equal volumes of $2 \times$ Laemmli sample buffer (Laemmli 1970). Proteins were resolved by $8.5 \%$ SDS-PAGE, and phosphorylated products were detected by autoradiography at $-70^{\circ} \mathrm{C}$ on Kodak $\mathrm{X}$-OMAT film. GST-Cdc25A protein or GST was purified as described previously (Galaktionov and Beach 1991). Typically, 5-10 $\mu \mathrm{g}$ of Cdc25A fusion or GST was incubated with 400-800 $\mu \mathrm{l}$ of the extracts from Sf9 cells coinfected with raf1 (wild type or K375M mutant), ras, and src baculoviruses for $4-8 \mathrm{hr}$ at $4^{\circ} \mathrm{C}$, followed by addition of $40 \mu \mathrm{l}$ of glutathione-sepharose slurry (1:1) for an additional 1-2 hr incubation. Beads were washed four times with $\mathrm{KB}$ and resuspended in $50 \mu \mathrm{l}$ of $\mathrm{KB}$. ATP $\gamma \mathrm{S}$ was added to $2 \mathrm{~mm}$, and samples were incubated for an additional 30 $\min$ at $30^{\circ} \mathrm{C}$. Beads were washed with cold phosphatase buffer $(\mathrm{PB})$, containing $50 \mathrm{~mm}$ Tris $\mathrm{HCl}(\mathrm{pH} 8.0), 50 \mathrm{~mm} \mathrm{NaCl}$, and 10 mM DTT and resuspended in PB, supplemented with $200 \mathrm{~mm}$ PNPP. Reaction mixtures were incubated at $30^{\circ} \mathrm{C}$ for $15-30 \mathrm{~min}$ (Fig. 5D) or 5-35 min (Fig. 5C); and phosphatase activity was assayed by measuring $\mathrm{OD}_{410}$. For the experiment described in (Figure 5E); extracts from Sf9 cells infected with Weel and GST-cyclin A/cdk2 baculoviruses were mixed, ATP regeneration system was added, and incubation continued for $30 \mathrm{~min}$ at $30^{\circ} \mathrm{C}$. Largely inactive GST-cyclin A/cdk 2 complexes were recovered on glutathione-Sepharose beads and eluted with $10 \mathrm{~mm}$ glutathione in $\mathrm{KB}$ (without vanadate). This material was mixed with GST-Cdc25A, treated as described above, eluted with 10 mM glutathione leach point represents threefold subsequent dilution of the eluted GST-Cdc25A starting from 1:27 (Fig. 5E,1) to $1: 1$ (Fig. 5E,4)l, and incubated for $10 \mathrm{~min}$. Histone $\mathrm{Hl}$ and $\mathrm{ATP} /\left|\gamma^{-32} \mathrm{P}\right| \mathrm{ATP}$ was added to $1 \mu \mathrm{g}$ and $50 \mu \mathrm{M} / 10 \mu \mathrm{Ci}$, and incubation continued for another $10 \mathrm{~min}$ at $30^{\circ} \mathrm{C}$. The supernatant was recovered, mixed with $2 \times$ Laemmli sample buffer, and run on an $8.5 \%$ SDS-polyacrylamade gel. The gel was dried and processed on Fuji Imager BAS2000 to quantitate the results of the kinase reaction.

\section{Indirect immunofluorescence}

Mouse embryo fibroblasts (MEF) stably transfected with cdc25A and Ha-ras (V12) were fixed with $3.7 \%$ formaldehyde for $10 \mathrm{~min}$, permeabilized by $0.1 \% \mathrm{NP}-40$ for $10-20 \mathrm{~min}$, treated with $3 \%$ BSA for 30-60 min, and stained with affinity-purified antibodies against the carboxy-terminal peptide of Cdc25A or Cdc25B (at $30 \mu \mathrm{g} / \mathrm{ml}$ ) and monoclonal antibodies against Ras (Y13-238) (Oncogene Sciences) or monoclonal antibodies against Raf 1 (Transduction Laboratories) at the same concentration. Indirect double immunofluorescence staining was done using FITC-conjugated goat anti-mouse or anti-rat secondary antibodies and Texas Red-conjugated goat anti-rabbit antibodies (Cappell). Coverslips were mounted in Immunomount with 1 $\mu \mathrm{g} / \mathrm{ml}$ of paraphenylendiamine. Microphotographs were taken on Zeiss Axiophot fluorescent microscope using PlanApochromat $63 \times$ objective.

\section{Acknowledgments}

We thank Drs. T. Roberts, D. Morrison, D. Morgan, H. PiwnicaWorms, and W. Dunphy for providing recombinant raf1, ras, src, GST-cyclin A, wee1, and cdk2 baculoviruses and Drs. W. Dunphy and $\mathrm{J}$. Maller for anti-Xenopus Cdc25 and cyclin B2 antibodies. We also thank M. Ockler, P. Renna, and J. Duffy for the artwork and Drs. J. Hudson, D. Conklin, G. Hannon, and M. Caligiuri for critical reading of the manuscript and valuable suggestions. Drs. H. Zhang and K. Okamoto are thanked for frequent helpful discussions. K.G. thanks I. Miloslavskaya for invaluable support. C.J. was on a short leave from CNRS, France. This research was supported by grants from the $\mathrm{Na}$ tional Institutes of Health. D.B. is an Investigator of the Howard Hughes Medical Institute.

The publication costs of this article were defrayed in part by payment of page charges. This article must therefore be hereby marked "advertisement" in accordance with 18 USC section 1734 solely to indicate this fact.

\section{References}

Ahn, N.G., R. Seger, R.L. Bratlien, C.D. Diltz, N.K. Tonks, and E.G. Krebs. 1991. Multiple components in an epidermal growth factor-stimulated protein kinase cascade. In vitro activation of a myelin basic protein/microtubule-associated protein 2 kinase. I. Biol. Chem. 266: 4220-4227.

Cowley, S., H. Paterson, P. Kemp, and C.J. Marshall. 1994. Activation of MAP kinase kinase is necessary and sufficient for $\mathrm{PCl} 2$ differentiation and for transformation of $\mathrm{NIH} 3 \mathrm{~T} 3$ cells. Cell 77: 841-852.

Dent, P., W. Haser, T.A.J. Haystead, L.A. Vincent, T.M. Robers, and T.W. Sturgill. 1992. Activation of mitogen-activated protein kinase kinase by v-Raf in NIH 3T3 cells and in vitro. Science 257: 1404-1407.

Draetta, G., H. Piwnica-Worms, D. Morrison, B. Druker, T. Roberts, and D. Beach. 1988. Human cdc2 protein kinase is a major cell-cycle regulated tyrosine kinase substrate. Nature 336: 738-744.

Dulic, V., W.K. Kaufmann, S.J. Wilson, T.D. Tlsty, E. Lees, J.W. Harper, S.J. Elledge, and S.I. Reed. 1994. p53-dependent inhibition of cyclin-dependent kinase activities in human fibroblasts during radiation-induced Gl arrest. Cell 76: 10131023.

Dunphy, W.G. and A. Kumagai. 1991. The cde25 protein contains an intrinsic phosphatase activity. Cell 67: 189-196.

Dunphy, W.G. and J.W. Newport. 1989. Fission yeast pl3 blocks mitotic activation and tyrosine dephosphorylation of the $\mathrm{Xe}$ nopus cdc2 protein kinase. Cell 58: 181-431.

El-Deiry, W.S., T. Tokino, V.E. Velculescu, D.B. Levy, R. Parsons, J.M. Trent, D. Lin, W.E. Mercer, K.W. Kinzler, and B. Vogelstein. 1993. WAF1, a potential mediator of p53 tumor suppression. Cell 75: 817-825.

Evans, T., E.T. Rosenthal, J. Youngblom, D. Distel, and T. Hunt. 1983. Cyclin: A protein specified by maternal mRNA in sea urchin eggs that is destroyed at each cleavage division. Cell 33: 389-396.

Fabian, J.R., D.K. Morrison, and I.O. Daar. 1993a. Requirement for Raf and MAP kinase function during the meiotic maturation of Xenopus oocytes. J. Cell Biol. 122: 645-652.

Fabian, J.R., I.O. Daar, and D.K. Morrison. 1993b. Critical tyrosine residues regulate the enzymatic and biological activity of Raf-l kinase. Mol. Cell Biol. 13: 7170-7173.

Featherstone, C. and P. Russell. 1991. Fission yeast pl07weel mitotic inhibitor is a tyrosine/serine kinase. Nature 349: 808-811.

Freed, E., M. Symons, S.G. Macdonald, F. McCormick, and R. Ruggieri. 1994. Binding of 14-3-3 proteins to the protein kinase Raf and effects on its activation. Science 265: 17131716.

Fu, H., K. Xia, D.C. Pallas, C. Cui, K. Conroy, R.P. Narsimhan, H. Mamon, R.J. Collier, and T.M. Roberts. 1994. Interaction of the protein kinase Raf-1 with $14-3-3$ proteins. Science 266: 126-129.

Galaktionov, K. and D. Beach. 1991. Specific activation of cdc25 tyrosine phosphatases by B-type cyclins: Evidence for mul- 
tiple roles of mitotic cyclins. Cell 67: 1181-1194.

Gautier, J., T. Matsukawa, P. Nurse, and J. Maller. 1989. Dephosphorylation and activation of Xenopus $\mathrm{p} 34 \mathrm{cdc} 2$ protein kinase during the cell cycle. Nature 339: 626-629.

Gautier, J., M. Solomon, R. Booher, J. Bazan, and M. Kirshner. 1991. Cdc25 is a specific tyrosine phosphatase that directly activates p34cdc2. Cell 67: 197-211.

Gomez, N. and P. Cohen. 1991. Dissection of the protein kinase cascade by which nerve growth factor activates MAP kinases. Nature 351: 69-72.

Gould, K. and P. Nurse. 1989. Tyrosine phosphorylation of the fission cdc $2+$ protein kinase regulates entry into mitosis. Nature 342: 39-45.

Gu, Y., J. Rosenblatt, and D.O. Morgan. 1992. Cell cycle regulation of cdk2 activity by phosphorylation of Thrl60 and Tyr15. EMBO I. 11: 3995-4005.

Gu, Y., C.W. Turck, and D.O. Morgan. 1993. Inhibition of CDK2 activity in vivo by an associated $20 \mathrm{~K}$ regulatory subunit. Nature 366: 707-710.

Guan, K.-L., C.W. Jenkins, Y. Li, M. Nichols, X. Wu, C. O'Keefe, A.G. Matera, and Y. Xiong. 1994. Growth suppression by p18, a pl6ink4/MTS1-and pl4 ink4B/MTS2-related CDK6 inhibitor, correlates with wild-type pRb function. Genes $\Leftrightarrow$ Development. 8: 2939-2952.

Haccard, O., B. Sarcevic, A. Lewellyn, R. Hartley, L. Roy, T. Izumi, E. Erikson, and J.L. Maller. 1993. Induction of the metaphase arrest in cleaving Xenopus embryos by MAP kinase. Science 262: 1262-1265.

Hannon, G.J. and D. Beach. 1994. p15INK4B is a potential effector of TGF- $\beta$ mediated cell cycle arrest. Nature 371: 257 261.

Harper, J.W., G.R. Adami, N. Wei, J. Keyomarsi, and S.J. Elledge. 1993. The p2l cdk-interacting protein Cipl is a potent inhibitor of G1 cyclin-dependent kinases. Cell 75: 805-816.

Heichman, K.A. and J. Roberts. 1994. Rules to replicate by. Cell 79: $557-562$.

Heidecker, G., M. Huleihel, J.L. Cleveland, W. Kolch, T.W. Beck, P. Lloyd, T. Pawson, and U.R. Rapp. 1990. Mutational activation of c-raf- 1 and definition of the minimal transforming sequence. Mol. Cell Biol. 10: 2503-2512.

Heidecker, G., W. Kolch, D.K. Morrison, and U.R. Rapp. 1991. The role of Raf-1 phosphorylation in signal transduction. Adv. Cancer Res. 58: 53-73.

Herskowitz, I. 1995. MAP kinase pathways in yeast: For mating and more. Cell 80: 187-197.

Hibi, M., A. Lin, T. Smeal, A. Minden, and M. Karin. 1993. Identification of an oncoprotein- and UV-responsive protein kinase that binds and potentiates the c-Jun activation domain. Genes \& Dev. 7: 2135-2148.

Hill, C.S. and R. Treisman. 1995. Transcriptional regulation by extracellular signals: Mechanisms and specificity. Cell 80: 199-211.

Hoffman, I., P.R. Clarke, M.J. Marcote, E. Karsenti, and G. Draetta. 1993. Phosphorylation and activation of human cdc25-C by cdc2/cyclin B and its involvement in the selfamplification of MPF at mitosis. EMBO /. 12: 53-63.

Hoffman, I., G. Draetta, and E. Karsenti. 1994. Activation of the phosphatase activity of human $\operatorname{cdc} 25 \mathrm{~A}$ by a cdk2-cyclinE dependent phosphorylation at the $\mathrm{G} 1 / \mathrm{S}$ transition. EMBO /. 13: $4302-4310$.

Howe, L. R., S.J. Leevers, N. Gomez, S. Nakielny, P. Cohen, and C.J. Marshall. 1992. Activation of the MAP kinase pathway by the protein kinase raf. Cell 71: 335-342.

Hunter, T. 1995. Protein kinases and phosphatases: The yin and yang of protein phosphorylation and signaling. Cell 80: 225236.
Hunter, T. and J. Pines. 1994. Cyclins and cancerII: CyclinD and cdk inhibitors come of age. Cell 79: 573-582.

Izumi, T. and J.L. Maller. 1991. Phosphorylation of Xenopus cyclins $\mathrm{B} 1$ and $\mathrm{B} 2$ is not required for cell cycle transitions. Mol. Cell Biol. 11: 3860-3867.

Izumi, T., D.H. Walker and J.L. Maller. 1992. Periodic changes in phosphorylation of the Xenopus cdc25 phosphatase regulate its activity. Mol. Cell Biol. 3: 1927-1939.

Jessus, C. and D. Beach. 1992. Oscillation of MPF is accompanied by periodic association between cdc 25 and cdc2-cyclin B. Cell 68: 323-332.

Jessus, C., C. Thibier, and R. Ozon. 1987. Levels of microtubules during the meiotic maturation of the Xenopus oocyte. I. Cell Sci. 87: 705-712.

Jinno, S., K. Suto, A. Nagata, M. Igarashi, Y. Kanaoka, H. Nojima, and H. Okayama. 1994. Cdc25A is a novel phosphatase functioning early in the cell cycle. EMBO $J$. 13: 1549-1556.

King, R.W., P.K. Jackson, and M.W. Kirshner. 1994. Mitosis in transition. Cell 79: 563-571.

Koff, A., F. Cross, A. Fisher, J. Schumacher, K. Leguallao, M. Phillippe, and J.M. Roberts. 1991. Human cyclin E, a new cyclin that interacts with two members of the cdc2 gene family. Cell 68: 1-20.

Kosako, H., Y. Gotoh, S. Matsuda, M. Ishikawa, and E. Nishida. 1992. Xenopus MAP kinase activator is a serine/threonine/ tyrosine kinase activated by threonine phosphorylation. $E M B O$ I. 11: 2903-2908.

Krek, W. and E.A. Nigg. 1991. Mutations of p34cdc2 phosphorylation sites induce premature mitotic events in HeLa cells: Evidence of a double block to $\mathrm{p} 34 \mathrm{cdc} 2$ kinase activation in vertebrates. $E M B O$ /. 10: 3331-3341.

Kumagai, A. and W.G. Dunphy. 1992. Regulation of the cdc25 protein during the cell cycle in Xenopus extracts. Cell 70: 139-151.

Kyriakis, J.M., H. App, X.F. Zhang, P. Baneriee, D.L. Brautigan, U.R. Rapp, and J. Avruch. 1992. Raf-1 activates Map kinasekinase. Nature 358: 417-421.

Laemmli, U.K. 1970. Cleavage of structural proteins during the assembly of the head of bacteriophage T4. Nature 227: 680685

Lange-Carter, C.A. and G.L. Johnson. 1994. Ras-dependent growth factor regulation of MEK kinase in PC12 cells. Science 265: 1458-1461.

Leevers, S.J., F.G. Paterson, and C.J. Marshall. 1994. Requirement for Ras in Raf activation is overcome by targeting Raf to the plasma membrane. Nature 369: 411-414.

Lew, D.J., V. Dulic, and S.I. Reed. 1991. Isolation of three novel human cyclins by rescue of $\mathrm{Gl}$ cyclin (cln) function in yeast. Cell 66: 1197-1206

Lundgren, K., N. Walworth, R. Booher, M. Dembski, M. Kirschner, and D. Beach. 1991. Mik1 and weel cooperate in the inhibitory tyrosine phosphorylation of cdc2. Cell 64: 11111122.

Marshall, C.J. 1995. Specificity of receptor tyrosine kinse signalling: Transient versus sustained extracellular signal-regulated kinase activation. Cell 80: 179-185.

Matsushime, H., M.F. Roussel, R.A. Ashmun, and C.J. Sherr. 1991. Colony-stimulating factor 1 regulates novel cyclins during the Gl phase of the cell cycle. Cell 65: 701-713.

Meyerson, M., G.H. Enders, C.-L. Wu, L.-K. Su, C. Gorka, C. Neilson, E. Harlow, and L.-H. Tsai. 1992. A family of human cdc2-related protein kinases. EMBO I. 11: 2909-2917.

Millar, J.B., C.H. McGowan, G. Lenaers, R. Jones, and P. Russell. 1991. p80cdc25 mitotic inducer is the tyrosine phosphatase that activates p34cdc2 kinase in fission yeast. $E M B O$ I. 10: 4301-4309. 
Minden, A., M. McMahon, C. Lange-Carter, B. Derijard, R.J. Davis, G.L. Johnson, and M. Karin. 1994. Differential activation of ERK and JNK MAP kinases by Raf-1 and MEKK. Science 266: 1719-1723.

Moria, A.O., G. Draetta, D. Beach, and J.Y. Wang. 1989. Reversible tyrosine phosphorylation of cdc2: Dephosphorylation accompanies activation during entry into mitosis. Cell 58: 193-203.

Muslin, A.J., A.M. MacNicol, and L.T. Williams. 1993. Raf-1 protein kinase is important for progesterone-induced Xenopus oocyte maturation and acts downstream of mos. Mol. Cell. Biol. 13: 4197-4202.

Nagata, A., M. Igarashi, S. Jinno, K. Suto, and H. Okayama. 1991. An additional homolog of the fission yeast cdc25+ gene occurs in humans and is highly expressed in some cancer cells. New Biol. 3: 959-968.

Noda, A., Y. Ning, S.F. Venable, O.M. Pereira-Smith, and J.R. Smith. 1994. Cloning of senescent cell-derived inhibitors of DNA synthesis using an expression screen. Exp. Cell Res. 211: 90-98.

Parker, L.L., S. Atherton-Fessler, M.S. Lee, S. Ogg, J.L. Falk, K.I. Swenson, and H. Piwnica-Worms. 1991. Cyclin promotes the tyrosine phosphorylation of p34cdc2 in a weel + dependent manner. EMBO /. 10: 1255-1263.

Parker, L., S. Atherton-Fessler, and H. Piwnica-Worms. 1992. pl07weel is a dual-specificity kinase that phosphorylates p34cdc2 on tyrosine 15. Proc. Natl. Acad. Sci. 89: 29172921.

Polyak, K., M.H. Lee, H. Erdjument-Bromage, A. Koff, J.M. Roberts, P. Tempst, and J. Massague. 1994a. Cloning of p27Kipl, a cyclin-dependent kinase inhibitor and a potential mediator of extracellular antimitogenic signals. Cell 78: 59-66.

Polyak, K., J.Y. Kato, M.J. Solomon, C.J. Sherr, J. Massague, J.M. Robcrts, and A. Koff. 1994b. p27Kipl, a cyclin-Cdk inhibitor, links transforming growth factor-beta and contact inhibition to cell cycle arrest. Genes \& Dev. 8: 9-22.

Rapp, U.R., G. Heidecker, M. Huleihel, J.L. Cleveland, W.C. Choi, T. Pawson, J.N. Ihle, and W.B. Anderson. 1988. Raf family serine/threonine protein kinases in mitogenic signal transduction. Cold Spring Harbor Symp. Quant. Biol. 53: $173-184$

Rodriguez-Viciana, P., P.H. Warne, R. Dhand, B. Vanhaesebroeck, I. Gout, M.J. Fry, M.D. Waterfield, and J. Downward. 1994. Phosphatidylinositol-3-OH kinase as a direct target of Ras. Nature 370: 527-532.

Rossow, P.W., V.G.H. Riddle, and A.B. Pardee. 1979. Synthesis of labile, serum-dependent protein in early G1 controls animal cell growth. Proc. Natl. Acad. Sci. 76: 4446-4450.

Russell, P. and P. Nurse. 1986. cdc25 + functions as an inducer in the mitotic control of fission yeast. Cell 45: 145-153.

1987. Negative regulation of mitosis by weel + , a gene encoding a protein kinase homolog. Cell 49: 559-567.

Sadhu, K., S.I. Reed, H. Richardson, and P. Russell. 1990. Human homolog of fission yeast cdc25 mitotic inducer is predominantly expressed in G2. Proc. Natl. Acad. Sci. 87: 51395143.

Sadler, S.E. and J.L. Maller. 1989. A similar pool of cyclic AMP phosphodiesterase in Xenopus oocytes is stimulated by insulin, insulin-like growth factor 1 , and $\left[\mathrm{Val}^{12}, \mathrm{Thr}^{59}\right]$ Ha-ras protein. J. Biol. Chem. 264: 856-861.

Sanchez, I., R.T. Hughes, B.J. Mayer, K. Yee, J.R. Woodgett, J. Avruch, J.M. Kyriakis, and L.I. Zon. 1994. Role of SAPK/ ERK kinase-1 in the stress-activated pathway regulating transcription factor c-Jun. Nature 372: 794-798.

Serrano, M., G. Hannon, and D. Beach. 1993. A new regulatory motif in cell cycle control causing specific inhibition of cy- clin D/CDK4. Nature 366: 704-707.

Sherr, C.J. 1994. G1-phase progression: cycling on cue. Cell 79: $817-825$.

Solomon, M., T. Lee, and M. Kirschner. 1992. The role of phosphorylation in p34cdk2 activation: Identification of an activating kinase. Mol. Biol. Cell 3: 13-27.

Stacey, D.W., M. Roudebush, R. Day, S.D. Mosser, J.B. Gibbs, and L.A. Feig. 1991. Dominant inhibitory Ras mutants demonstrate the requirement for Ras activity in the action of tyrosine kinase oncogenes. Oncogene 6: 2297-2304.

Stanton, V.P. Jr., D.W. Nichols, A.P. Laudano, and G.M. Cooper. 1989. Definition of the human raf amino-terminal regulatory region by deletion mutagenesis. Mol. Cell Biol. 9: 639647.

Stokoe, D., S.G. Macdonald, K. Cadwallader, M. Symons, and J.F. Hancock. 1994. Activation of Raf as a result of recruitment to the plasma membrane. Science 264: 1463-1467.

Strausfeld, U., J.C. Labbe, D. Fesquet, J.C. Cavadore, A. Picard, K. Sadhu, P. Russell, and M. Doree. 1991. Dephosphorylation and activation of a $\mathrm{p} 34 \mathrm{cdc} 2$ cyclin-B complex in vitro by human cdc25 protein. Nature 351: 242-245.

Swenson, K.I., K.M. Farrell, and J.V. Ruderman. 1986. The clam embryo protein cyclin A induces entry into $M$ phase and the resumption of meiosis in Xenopus oocytes. Cell 47: 861870.

Thomas, S.M., M. DeMarco, G. D'Arcangelo, S. Halegoua, and J.S. Brugge. 1992. Ras is essential for nerve growth factorand phorbol ester-induced tyrosine phosphorylation of MAP kinases. Cell 68: 1031-1040.

Toyoshima, H. and T. Hunter. 1994. p27, a novel inhibitor of G1 cyclin-cdk protein kinase activity, is related to $\mathrm{p} 21$. Cell 78 : 67-74.

Traverse, S., P. Cohen, H. Paterson, C. Marshall, U. Rapp, and R.J. Grand. 1993. Specific association of activated MAP kinase kinase kinase (Raf) with the plasma membranes of rastransformed retinal cells. Oncogene 8: 3175-3181.

van Aelst, L., M. Barr, S. Marcus, A. Polverino, and M. Wigler. 1993. Complex formation between RAS and RAF and other protein kinases. Proc. Natl. Acad. Sci. 90: 6213-6217.

Wartmann, M. and R.J. Davis. 1994. The native structure of the activated Raf protein kinase is a membrane-bound multisubunit complex. I. Biol. Chem. 269: 6695-6701.

Williams, N.G., T.M. Roberts, and P. Li. 1992. Both p21 ${ }^{\text {ras }}$ and pp $60^{\text {src }}$ are required, but neither alone is sufficient, to activate the Raf-1 kinase. Proc. Natl. Acad. Sci. 89: 2922-2926.

Williams, N.G., H. Paradis, S. Agarwal, D.L. Charest, S.L. Pelech, and T.M. Roberts. 1993. Raf-1 and p21v-ras cooperate in the activation of mitogen-activated protein kinase. Proc. Natl. Acad. Sci. 90: 5772-5776.

Won, K.A., Y. Xiong, D. Beach, and M.Z. Gilman. 1992. Growth-regulated expression of D-type cyclin genes in human diploid fibroblasts. Proc. Natl. Acad. Sci. 89: 99109914.

Wood, K.W., C. Sarnecki, T.M. Roberts, and J. Blenis. 1992. Ras mediates nerve growth factor receptor modulation of three signal-transducing protein kinases: MAP kinase, Raf-1, and RSK. Cell 68: 1041-1050.

Xiong, Y., T. Connolly, B. Futcher, and D. Beach. 1991. Human D-type cyclin. Cell 65: 691-699.

Xiong, Y., G. Hannon, H. Zhang, D. Casso, R. Kobayashi, and D. Beach. 1993. p21 is a universal inhibitor of cyclin kinases. Nature 366: 701-704.

Yan, M., T. Dai, J.C. Deak, J.M. Kyriakis, L.I. Zon, J.R. Woodgett, and D.J. Templeton. 1994. Activation of stressactivated protein kinase by MEKK1 phosphorylation of its activator, SEK1. Nature 370: 798-801. 


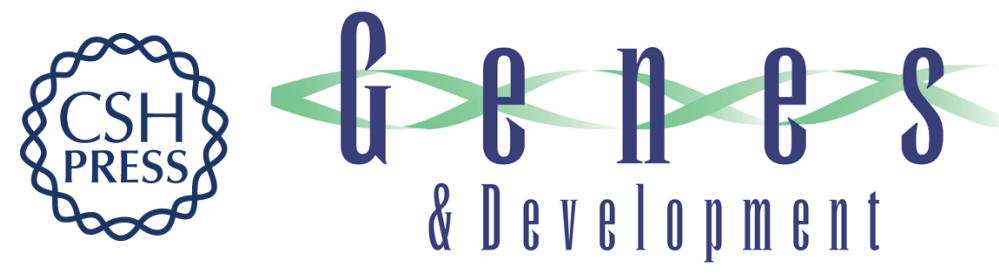

\section{Raf1 interaction with Cdc25 phosphatase ties mitogenic signal transduction to cell cycle activation.}

$K$ Galaktionov, C Jessus and D Beach

Genes Dev. 1995, 9:

Access the most recent version at doi:10.1101/gad.9.9.1046

References This article cites 93 articles, 29 of which can be accessed free at: http://genesdev.cshlp.org/content/9/9/1046.full.html\#ref-list-1

License

Email Alerting Service right corner of the article or click here.

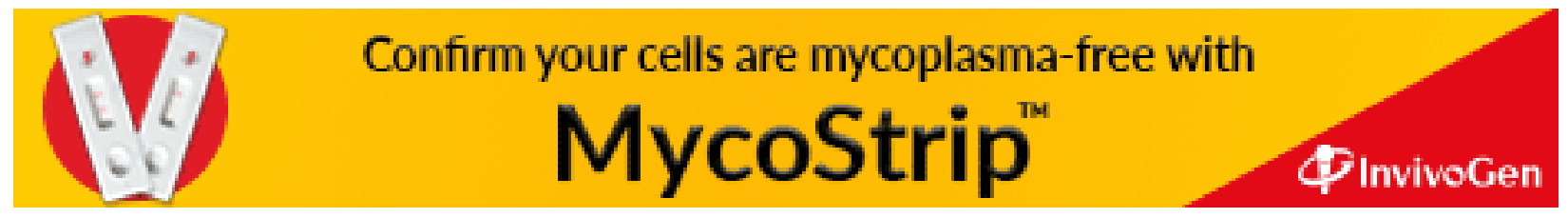

